Kirja-arviot

\title{
Pirunkaupat ja niiden tekijät
}

\author{
Purola, Mari. 2019. Sopimus pirun kanssa. Piru ja ihminen toimijoina \\ suomalaisissa uskomustarinoissa 1840-1960. Publications of the University of \\ Eastern Finland. Dissertations in Education, Humanities, and Theology No. \\ 147. Joensuu: University of Eastern Finland. 168 sivua. \\ https://erepo.uef.fi/bitstream/handle/123456789/21800/urn isbn 978-952- \\ 61-3222-8.pdf
}

\section{Pasi Enges}

$\mathrm{M}$ ari Purolan väitöstutkimuksen aiheena ovat uskomustarinat, joiden juoni punoutuu pirun ja ihmisen solmiman sopimuksen ympärille. Piru on suomalaisen uskomusperinteen ehkä moniulotteisin olento, joka esiintyy tarinaperinteessä ja muissa perinnelajeissa monenlaisissa rooleissa. Sillä on ollut keskeinen asema kristillisen kirkon opetuksissa Jumalan perivihollisena ja äärimmäisen pahuuden henkilöitymänä. Kansanuskossa ja sitä ilmentävässä folkloressa piru on puolestaan ollut milloin uhkaava ja pahantahtoinen, milloin taas avulias, naurettava tai säälittävä hahmo. Luultavasti juuri sijoittuminen kahden toisiinsa monin tavoin vaikuttaneen tradition välimaastoon on tehnyt pirusta sekä kansanperinteessä keskeisen usko-

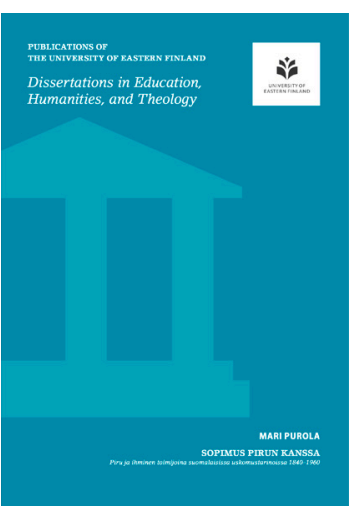
musolennon että suositun tutkimuskohteen, niin Suomessa kuin kansainvälisestikin. Suomessa pirun ja ihmisen solmimaa sopimusta on käsitelty tai ainakin sivuttu useammassakin folkloristisessa tutkimuksessa (esim. Danielsson 1932; Wolf-Knuts 1991; Klemettinen 1997; Piispanen 2009), mutta Purolan väitöskirja on ensimmäinen tähän aiheeseen perusteellisesti syventyvä työ.

Tutkimus rakentuu kahdeksasta pääluvusta. Johdannossa käydään asianmukaisesti läpi aineiston syntyyn ja muodostumiseen vaikuttaneet taustatekijät, esitellään tutkimuskysymykset, pohditaan tutkimusetiikkaa ja esitellään aikaisempaa tutkimusta. Toinen pääluku pitää sisällään työn metodologiset ratkaisut ja keskeiset käsitteet sekä uskomustarinagenren tarkastelua, kolmannessa pääluvussa puolestaan käsitellään tutkimuskohteena olevien kertomusten kirjallista taustaa. Tästä eteenpäin ollaan jo primaariaineiston analyysin parissa. Luvussa 4 eritellään tarinatyyppejä ja niiden juonenkulkuja, luvussa 5 taas pirun nimityksiä ja ulkonäköä. Luku 6, "Sopimus toimintana" on nähdäkseni tutkimuksen keskeisin; siinä analysoidaan sopimuksen syntyä, sen osapuolia ja näiden tavoittelemia hyötyjä sekä sopimuksen seurauksia. Seitsemännessä luvussa nostetaan esiin analyysin paljastamia alueellisia 
eroja ja painotuksia, ja viimeisessä kootaan yhteen ja arvioidaan tutkimuksessa saavutettuja tuloksia.

\section{Perusfolkloristista sisällönanalyysia}

Tutkimuksen aineiston muodostavat Suomalaisen Kirjallisuuden Seuran arkiston uskomustarinakortiston tyyppiluokat E501-600 (Liitto pirun kanssa) sekä jotkut luokan E1001-1100 (Piru houkuttaa pahuuteen, kiusaa ja tappaa tai "auttaa" ja avustaa) tarinatyypeistä, yhteensä 1119 muistiinpanoa. Näistä tekijä käyttää yhteisnimitystä sopimuskertomus. Tutkimuskysymyksiä on neljä, joista ensimmäinen on luonteeltaan kuvaileva: minkälaisia ovat suomalaiset sopimuskertomukset? Tähän kysymykseen haetaan vastausta piirreanalyysilla, mikä käytännössä merkitsee jokaisen muistiinpanon sisällöllisen aineksen varsin yksityiskohtaista erittelyä. Käytännöllisenä, epäilemättä paljon työtunteja vaatineena menetelmänä Mari Purola on soveltanut taulukointia, jossa analyysin kohteeksi määriteltyjen piirteiden esiintyminen ja sisältö kirjataan muistiinpanokohtaisesti. Tällaisia piirteitä ovat kertomuksen henkilöt, näiden nimitykset ja luonnehdinnat, sopimuksen aika ja paikka, sen sisältö ja ehdot, siitä vapautumisen mahdollisuudet sekä sopimuksen solmimista seuraavat tapahtumat. Koko tutkimusaineiston kattava taulukointi on mahdollistanut yksittäisiin piirteisiin kohdistuvien hakujen tekemisen ja niiden esiintyvyyden, variaation ja kytkösten selvittämisen.

Vaikuttaa siltä, että analyysin kohteeksi valikoituneet piirteet ovat nousseet luontevasti esiin tutkimusaineistosta. Koska kysymyksessä on väitöskirja ja koska piirreanalyysi on työn keskeinen menetelmä ja piirre sen keskeinen analyyttinen yksikkö, olisin kuitenkin toivonut menetelmän ja käsitteistön tarkempaa esittelyä ja määrittelyä. Kuvatessaan menetelmäänsä (s. 33) tekijä ei viittaa kehenkään tutkijaan tai aikaisempaan julkaisuun, ja perustelee varsin niukasti menetelmävalintaansa ja sen ilmeistä hyödyllisyyttä. Ymmärtääkseni piirreanalyysia käytetään tässä synonyymina varhaisemmassa folkloristiikassa yleisesti hyödynnetylle ja nimityksenä paremmin tunnetulle motiivianalyysille. Purola tekee eron motiivin ja piirteen välille tarkoittaen edellisellä kertomuksen ydintä, toisin sanoen päämotiivia, jonka perusteella juoni on tunnistettavissa ja määriteltävissä tiettyyn tarinatyyppiin kuuluvaksi. Lisäksi hän puhuu juonellisista elementeistä. Tieteen termipankissa motiivin vastineeksi nimetään sekä piirre että aihelma ja elementti (Tieteen termipankki 11.10.2021). Koska tällaiset sisällöllisen yksikön käsitteet eivät ole yksiselitteisiä, olisi käyttöön valittujen tarkempi määrittely ja myös viittaaminen taustalla olevaan tieteelliseen keskusteluun ollut paikallaan. lästään huolimatta esimerkiksi Anna Birgitta Roothin (1951) ja Stith Thompsonin (1955), tai tuoreempana Heda Jasonin (2000) julkaisut ovat käyttökelpoisia. Näin erityisesti siksi, että menneinä vuosikymmeninä motiivianalyysia on tehty toisenlaisista lähtökohdista ja toisenlaisin tavoittein, ja Purola on halunnut omalla tutkimuksellaan osoittaa analyysitavan käyttökelpoisuuden myös nykytutkimuksessa. On toki myös todettava, että teorian ohuus ei ole ollut este onnistuneesti toteutetulle analyysille, jonka tuloksista useita on esitetty myös kvantifioiden ja taulukkomuodossa.

\section{Toimijuuksia ja alueellista variaatiota}

Kuten menetelmän grand old man Stith Thompson (1955) on todennut, motiivianalyysi on usein varsinaista tutkimusta edeltävää "lapiotyötä", aineiston sisältöjen ja niissä toistuvien piirteiden löytämistä, kuvailua ja luokittelua. Näin on myös Purolan väitöskirjassa: sisältöjen kuvaus on pohjana sopimuskertomusten asemaa ja merkitystä koskeville tulkinnoille. 
Keskeinen käsite on kertomushahmojen (sopimusosapuolten) toimijuus, jota analysoidaan A. J. Greimasin aktanttimallin sovelluksella. Toinen tutkimuksen pääkysymyksistä kohdistuukin sopimuskertomuksissa välittyviin sosiaaliseen hierarkiaan ja sukupuoleen liittyviin käsityksiin. Sopimukseen ryhtyvän valta, hänen kompetenssinsa toimia tilanteessa ja mahdollisuutensa vaikuttaa sopimuksen sisältöön tai myöhemmin irtautua siitä vaihtelevat ihmisen sosiaalisen aseman ja sukupuolen mukaan, ja vastaavasti vaihtelee myös pirun rooli.

Sopimuskertomusten tulkinnassa keskeistä on niiden kontekstualisointi, kertomusten kulttuuristen yhteyksien osoittaminen ja tarkastelu. Yksittäisellä kertomusmuistiinpanolla on useita rinnakkaisia konteksteja, sekä tekstuaalisia että maantieteellisiä. Yhtäältä tekstuaalisena kontekstina on arkistoidusta uskomustarina-aineistosta muodostettu korpus, primaariaineisto, jota tarkastellaan kokonaisuutena ja johon yksittäisiä muistiinpanoja suhteutetaan. Toisaalta kontekstina toimivat muut samaa aihetta käsittelevät folkloren lajit, kuten pirun humoristisesti esittävät pilasadut ja kaskut. Merkittävä osa tekstuaalista kontekstia on myös aihepiiriin liittyvä kirjallinen traditio.

Väitöskirjan kolmanneksi tutkimuskysymykseksi onkin määritelty sopimuskertomusten yhteydet kirjallisiin lähteisiin. Monet suullisena perinteenä taltioiduista sopimuskertomusten keskeismotiiveista tunnetaan kristillisessä kirjallisuudessa, ennen kaikkea Raamatussa ja vuoden 1701 virsikirjassa, sekä eurooppalaisissa Faust-kertomuksissa. Kysymys saa tutkimuksessa varsin suppean käsittelyn, mutta suomalaiset sopimuskertomukset ja niiden keskeiset elementit osoittautuvat kansainvälisen tradition paikallisesti sopeutuneiksi ja usein myös kristillisten käsitysten kanssa ristiriitaisiksi muodoiksi.

Neljäs pääkysymys kohdistuu kertomusten maantieteelliseen variaatioon. Vaikka pirun ja ihmisen välisestä sopimuksesta kertovia uskomustarinoita on taltioitu koko Suomen alueelta, paljastaa koko aineistoon kohdistettu piirreanalyysi suuriakin alueellisia eroja ja paikallisia ominaispiirteitä. Perinne-ekologiansa lukeneille on tuttua, miten alueen luonnonympäristö, elinkeinot ja sosiaalinen miljöö heijastuvat folkloreen. Sopimuskertomusaineistosta erottuvat läntinen (Faust-kertomusten pirua muistuttava) herrapiru ja sen sopimuskumppani, yläluokkainen friimuurari, itäsuomalaisen metsästäjän kohtaama haltijatyyppinen metsäpiru ja keskisen Suomen kaskipiru. Kun muilla alueilla sopimuksen solmineella on erilaisia mahdollisuuksia vapautua sitoumuksestaan (esimerkiksi papin antama turva tai oma oveluus), pohjoisilla perinnealueilla itsensä pirulle vapaaehtoisesti luvannut on peruuttamattomasti pirun oma.

\section{Maailmankuvan jäljillä}

Kuten tekijä eri kohdissa työtään muistuttaa, sopimuskertomusten analyysin perimmäinen tavoite on menneisyydessä eläneiden ihmisten ajatusmaailman ja heidän elämänsä todellisuuden tavoittaminen. Pirua - ja uskomusperinteessä laajemmin muitakin uskomusolentoja - koskevissa kertomuksissa moraaliset kysymykset ovat usein keskeisiä. Niissä peilataan inhimillisiä hyveitä ja heikkouksia, ilmaistaan ja koetellaan oikean ja väärän häilyvää rajapintaa, ja välitetään näkemyksiä hyvästä elämästä. Lopulta kyseessä on siis arkistoaineiston kautta avautuvan maailmankuvan tutkimus.

Mari Purolan väitöskirja Sopimus pirun kanssa rakenteellisesti ja sisällöllisesti tieteellisen tutkimuksen kriteerit hyvin täyttävä työ. Monia näkökulmia yhdistävänä tutkimus ehkä jää 
teoreettisesti ja metodologisesti hieman hapuilevaksi, mutta vähintäänkin se toimii erinomaisena perusselvityksenä aiheestaan. Vanhan (mutta ei suinkaan vanhentuneen) analyysimenetelmän soveltaminen on virkistävä muistutus siitä, mitä annettavaa perinteisellä, laajaan aineistoon pohjautuvalla "perusfolkloristisella" lähestymistavalla voi olla nykytutkimuksessa, ja sisällöllisessä rikkaudessaan työ on pirun kiinnostava lukukokemus.

\section{Kirjallisuus}

Danielsson, Paul. 1932. Djävulgestalten i Finlands svenska folktro. Il. Djävulen i människogestalt. Bidrag till kännedom av Finlands natur och folk, H. 84, N:o 2. Helsingfors: Finska vetenskaps-societeten.

Jason, Heda. 2000. Motif, Type and Genre. A Manual for Compiling of Indices \& A Bibliography of Indices and Indexing. Folklore Fellow's Communicatios 273. Helsinki: Academia Scientiarum Fennica.

Klemettinen, Pasi. 1997. Mellastavat pirut. Tutkimus kansanomaisista paholais- ja noituuskäsityksistä Karjalan Kannaksen ja Laatokan Karjalan tarinaperinteessä. Suomalaisen Kirjallisuuden Seuran Toimituksia 687. Helsinki: Suomalaisen Kirjallisuuden Seura.

Piispanen,Sirkku. 2009. Kansanomainen moraali. Tutkimus savolaisista ja pohjalaisista uskomustarinoista. Helsinki: Yliopistopaino.

Rooth, Anna Birgitta. 1951. The Cinderella Cycle. Lund: C.W.K. Gleerup.

Thompson, Stith. 1955. Narrative Motif-Analysis as a Folklore Method. Folklore Fellow's Communicatios 161. Helsinki: Academia Scientiarum Fennica.

Tieteen termipankki. 11.10.2021. Folkloristiikka: motiivi. https://tieteentermipankki.fi/wiki/ Folkloristiikka:motiivi.

Wolf-Knuts, Ulrika. 1991. Människan och djävulen. En studie kring form, motiv och funktion i folklig tradition. Åbo: Åbo Akademis förlag.

FT Pasi Enges on folkloristiikan yliopistonlehtori Turun yliopistossa. 